\title{
Efficiency of small mammal trapping in an Atlantic Forest fragmented landscape: the effects of trap type and position, seasonality and habitat
}

\author{
Vieira, ALM. ${ }^{a *}$, Pires, AS. ${ }^{a, b}$, Nunes-Freitas, AF ${ }^{a, b}$, Oliveira, NM. ${ }^{c}$, \\ Resende, $A S^{c}{ }^{c}$ and Campello, EFC. ${ }^{c}$ \\ aPrograma de Pós-graduação em Ciências Ambientais e Florestais, Universidade Federal Rural do Rio de Janeiro - UFRRJ, \\ Rodovia BR 465, Km 07, CEP 23890-000, Seropédica, RJ, Brazil \\ 'Departamento de Ciências Ambientais, Instituto de Florestas, Universidade Federal Rural do Rio de Janeiro - UFRRJ, \\ Rodovia BR 465, Km 07, CEP 23890-000, Seropédica, RJ, Brazil \\ 'Embrapa Agrobiologia, Rodovia BR 465, Km 07, CEP 23890-000, Seropédica, RJ, Brazil \\ *e-mail: andre.macedo@icmbio.gov.br
}

Received: June 13, 2012 - Accepted: May 11, 2013 - Distributed: August 31, 2014

\begin{abstract}
Trapping methods can strongly influence the sampling of mammal communities. This study compared the efficiency of the capture of small mammals in Sherman traps in two positions (at ground level and in trees) and pitfall traps in a fragmented landscape. Trapping sessions were carried out between October 2008 and October 2009 at two fragments ( 8 and $17 \mathrm{ha}$ ), an agroforest corridor between them, and the adjacent pasture. A total effort of 4622 trap-nights resulted in 155 captures of 137 individuals from six species. Pitfalls had greater success (4.03\%), followed by Shermans on the ground $(2.98 \%)$ and on trees $\left(2.37 \% ; \chi^{2}=6.50, p=0.04\right)$. Five species were caught in Sherman ground traps, four in pitfalls and just two on trees. There was no difference among trap types for marsupials $\left(\chi^{2}=4.75 ; p=0.09\right)$, while for rodents, pitfalls were more efficient than Shermans on the ground (Fisher's exact test, $p=0.02$ ). As a result, the efficiency of each trap type differed among habitats, due to differences in their species composition. Pitfalls were more efficient in the rainy season (Fisher's exact test, $\mathrm{p}<0.0001$ ) while Shermans on trees were more efficient in the dry season (Fisher's exact test, $\mathrm{p}=0.009$ ). There was no difference between seasons for Shermans on the ground (Fisher's exact test, $p=0.76$ ). Considering the results found, we recommend that future studies of forest mammal communities, particularly those designed to test the effects of forest fragmentation, include combinations of different trap types.
\end{abstract}

Keywords: pitfall traps, Sherman traps, trap efficiency, marsupials, rodents.

\section{Eficiência da captura de pequenos mamíferos em uma paisagem fragmentada de Mata Atlântica: efeitos do tipo e posição das armadilhas, estação do ano e habitat}

\section{Resumo}

O método de captura pode influenciar a amostragem de comunidades de pequenos mamíferos. Este estudo comparou a eficiência de captura de pequenos mamíferos em armadilhas Sherman em duas posições (solo e árvores) e armadilhas de queda em uma paisagem fragmentada. As sessões de armadilhagem foram realizadas entre outubro de 2008 e outubro de 2009 em dois fragmentos ( 8 e 17 ha), no corredor agroflorestal que liga os fragmentos e na pastagem adjacente. Um esforço total 4622 armadilhas-noites resultou em 155 capturas de 137 indivíduos de seis espécies. Os pitfalls apresentaram o maior sucesso de captura (4,03\%), seguido pelas Shermans no chão $(2,98 \%)$ e em árvores $(2,37 \%$; $\left.\chi^{2}=6,50, p=0,04\right)$. Cinco espécies foram capturadas em armadilhas Sherman chão, quatro em pitfalls e apenas duas em árvores. Não houve diferença entre os tipos de armadilhas para os marsupiais $\left(\chi^{2}=4,75, \mathrm{p}=0,09\right)$, enquanto que para os roedores, os pitfalls foram mais eficientes que Shermans chão (teste exato de Fisher, $p=0,02$ ). A eficiência de cada tipo de armadilha diferiu entre os habitats devido à diferenças na composição de espécies em cada área. Pitfalls foram mais eficientes na estação chuvosa (teste exato de Fisher, $\mathrm{p}<0,0001$ ) enquanto Shermans em árvores foram mais eficientes na estação seca (teste exato de Fisher, $\mathrm{p}=0,009$ ). Não houve diferença entre as estações para Shermans no chão (teste exato de Fisher, $\mathrm{p}=0,76$ ). Considerando os resultados encontrados, recomenda-se que futuros estudos de comunidades florestais de pequenos mamíferos, particularmente aqueles projetados para testar os efeitos da fragmentação florestal, considerem combinações de diferentes tipos de armadilhas.

Palavras-chave: armadilhas de queda, armadilhas Sherman, eficiência de captura, marsupiais, roedores. 


\section{Introduction}

Studies on the structure and functioning of small mammal communities are dependent on an adequate sampling of the whole community, which is strongly influenced by the capture technique chosen (Woodman et al., 1996). Some trap types may be more efficient in the capture of some species than others (Slade et al., 1993; O'Farrell et al., 1994; Lee, 1997). Trap efficiency may be affected by several factors, such as their own shapes (Woodman et al., 1996), spacing between them (Slade and Russell, 1998), position (Freitas and Fernandez, 1998), baits used (Laurance, 1994; O' Farrell et al., 1994), gender and age of animals, and availability of food sources in the environment (Adler and Lambert, 1997); which can be affected by climatic seasons (Bergallo and Magnusson, 1999; Santos-Filho et al., 2008). These factors become even more relevant in tropical rainforests, due to their great diversity of small mammals with different habits, which vary from semifossorial to arboreal species.

Most studies evaluating small mammals trapping success in the Brazilian Atlantic Forest compared types and position of traditional live traps (Freitas and Fernandez, 1998; Silva, 2001; Schittini et al., 2002; Astúa et al., 2006), while few compared also the success of pitfall traps (Umetsu et al., 2006). Additionally, in most of them, just one habitat was evaluated. However, in fragmented landscapes, alterations in the animal's spatial patterns - like increases or decreases in home range size and distances travelled (e.g. Pires et al., 2002; Lira et al., 2007) - can lead to differences in the efficiency of different trap types.

In this paper we assessed trap efficiency using Sherman traps in two positions (at ground level and in trees) and pitfall traps in an Atlantic Forest fragmented landscape located in Seropédica municipality, southeastern Brazil. The capture success of each trap type was compared (1) between marsupials and rodents; (2) among different habitats (fragments, corridor and pasture); and (3) between dry and wet seasons.

\section{Material and Methods}

The study was carried out in a fragmented landscape located at the Embrapa Agrobiologia campus, in an area locally known as Fazendinha Agroecológica do km 47 (22 46' 29'S and 43 41' 32'W), Seropédica municipality, Rio de Janeiro state, southeastern Brazil. The climate of the region is warm tropical with average annual temperatures above $23{ }^{\circ} \mathrm{C}$. Average annual precipitation reaches 1300 $\mathrm{mm}$ and its distribution is concentrated from September to March (mean \pm sd of mensal precipitation $=166.4 \pm 62.7$ ), with a dry season in the winter $(63.0 \pm 23.9)$.

The studied landscape comprised two fragments (named A and B), linked by an agroforestry corridor and the adjoining pasture. Fragment A, located on a small hill in the upper part of the terrain, has 8 ha and is a remnant of the Brazilian Atlantic Forest in a secondary succession stage. Its most representative species are Anadenanthera colubrina (Vell.) Brenan, Astronium graveolens Jacq.,
Sparattosperma leucanthum (vell.) k. schum., and Brosimum guianense (Aubl.) Huber, and the most common families are Fabaceae, Anacardiaceae and Bignoniaceae. Fragment $\mathrm{B}$, of $17 \mathrm{ha}$, is positioned in a flat area, originated from an old forest garden abandoned in the 1950s. Its most representative species are Mimosa caesalpiniifolia Benth., A. colubrina, and Aegiphila sellowiana Cham, and the most common families are Fabaceae, Myrtaceae, and Verbenaceae. Fragment A has higher tree diversity than fragment B; from the 63 tree species that occur in the fragments, only $19 \%$ are in common (Vieira, 2007). The corridor linking the fragments is $200 \mathrm{~m}$ by $30 \mathrm{~m}$ wide, totalling 0.6 ha. It was established as an agroforestry system in February 2005 and its more representative species are leguminous trees (Acacia angustissima Mill., Anadenanthera sp., Inga semialata Vell., Mimosa artemisiana Heringer e Paula and Piptadenia gonoacantha (Mart.) J.F. Macbr) and cultivated species such as banana, guava, manioc, pineapple, pumpkin, and sugar cane. The system was designed according to the model of analogous regenerative agroforestry system (Vivan, 1998). The matrix adjacent to the corridor is a pastureland composed mostly of guinea grass (Panicum maximum Jacq.) and regularly used by cattle and frequently mowed.

Small mammals were monthly sampled in each area (fragments, corridors and pasture) from October 2008 to October 2009, comprising 13 capture sessions each of four consecutive nights.

Two types of traps were used simultaneously, a Sherman live trap model XLF-15 $(10 \times 11.5 \times 38 \mathrm{~cm})$ and pitfalls made with 651 plastic buckets ( $40 \mathrm{~cm}$ diameter, and $65 \mathrm{~cm}$ depth). Shermans were placed in two distinct positions, on the ground and on trees (between 1.5 and $2 \mathrm{~m}$ in height). Traps in trees were considered a third kind of trap in the analyses. Pitfalls were positioned in Y-shaped systems with four pitfalls spaced $5 \mathrm{~m}$ from each other, linked by a $1 \mathrm{~m}$ height plastic drift fence. One pitfall was placed in the $\mathrm{Y}$ centre and the other three at the ends. Three pitfall systems were set in each sampling site, $80 \mathrm{~m}$ from each other. Seven Sherman traps were placed between each system, $10 \mathrm{~m}$ apart. Traps were set alternately on the ground and in the trees, resulting in a total of 14 live traps in each habitat. Baits were made from a mixture of banana, oat, bacon, and peanut butter. All traps were baited, including pitfalls, to prevent animal death from starvation. Besides that, pitfalls received a plastic coverage ca. $1 \mathrm{~m}$ above them and had their bottom perforated to reduce water accumulation. Additionally, each pitfall received a circular Styrofoam piece to permit that animals could avoid drowning in case of flooding following intense rain. All these procedures were used to reduce the mortality of the individuals, and proved to be efficient.

Total sampling effort was 4622 trap-nights, similarly divided among the four habitats. Small differences observed in the sampling effort among areas were due to logistical problems, such as soil flooding. Besides, Sherman tree traps were not used in the pasture, due to absence of trees to set them. 
Capture success was obtained by multiplying the total captures by 100 and dividing it by the sampling effort in trap-nights. Sherman traps in trees were not considered for the calculation of the capture success of exclusively terrestrial species.

In order to assess possible differences in capture success of small mammals among the traps used (Sherman ground, Sherman tree and pitfalls), we used the chi-square test (Zar, 1999). This analysis was also used to assess differences in capture success between dry (April to August) and rainy months (September to March). Whenever the chi-square assumptions were not met, Fisher's exact test was used (Zar, 1999). Tests were performed considering all small mammal captures, different taxonomic groups (rodents and marsupials), different habitats (fragments, corridor and pasture), and also separately for each species.

\section{Results}

\subsection{Efficiency of capture among trap types}

We obtained a total of 155 captures of 137 individuals belonging to six species of small mammals (Table 1). The higher number of species was caught in Sherman ground traps $(\mathrm{n}=5)$, followed by pitfalls $(4)$ and Sherman tree traps (2; Table 1). From the total captures, 88 (56.8\%) were achieved in pitfalls, $45(29.0 \%)$ in Sherman ground traps and $22(14.2 \%)$ in Sherman tree traps (Table 1). Results revealed a significantly higher capture success by pitfalls, followed by Sherman ground and Sherman tree traps $\left(\chi^{2}=6.50, \mathrm{p}=0.040\right.$; Table 1$)$.

Considering each taxonomic group separately, results showed no significant differences in capture success among the three trap types for marsupials $\left(\chi^{2}=4.75 ; p=0.09\right)$. For rodents, however, caught only in pitfall and Sherman ground traps, the capture success was significantly higher for the pitfalls (Fisher's exact test: $\mathrm{p}=0.02$; Table 2).
The comparison of trap capture efficiency within the same species was possible just for Didelphis aurita Wied-Neuwied 1826 and the rodents Oligoryzomys nigripes Olfers 1818 and Akodon cursor Winge 1887. For $D$. aurita, which was caught with all three types, the capture efficiency did not differ among trap types $\left(\chi^{2}=4.18\right.$, $\mathrm{p}=0.124)$. For terrestrial rodents, which used just two trap types, $O$. nigripes was significantly more frequently captured in pitfalls (Fisher's exact test: $\mathrm{p}=0.020$ ) while for A. cursor the difference was not significant (Fisher's exact test: $\mathrm{p}=0.587$; Table 1 ).

\subsection{Efficiency of trap types in different habitats}

Regarding all captured individuals, capture efficiency of traps differed among habitats. In fragment A and in the corridor, pitfalls were the most efficient method, followed by Sherman ground and Sherman tree traps (Fragment A: $\left.\chi^{2}=6.21, p=0.045 ; C: \chi^{2}=7.38, p=0.025\right)$. In fragment $\mathrm{B}$ there was no significant difference between trap types $\left(\chi^{2}=2.11, p=0.350\right)$, whereas Sherman ground was more efficient than pitfalls in the pasture (Fisher's exact test: $\mathrm{p}=0.025$; Table 1)

\subsection{Effects of season on trap capture efficiency}

In the wet season pitfalls were the most efficient, followed by Sherman ground and Sherman tree traps $\left(\chi^{2}=39.39\right.$, $\mathrm{p}<0.0001)$. In the dry season this pattern inverted, with Sherman trees having higher capture success, followed by Sherman ground and pitfalls $\left(\chi^{2}=19.05, \mathrm{p}<0.0001\right)$. Comparing separately each trap type between seasons, contrasting results were also acquired. Pitfalls were significantly more efficient in the wet season (Fisher's exact test: $\mathrm{p}<0.0001)$, whereas Sherman tree traps were more efficient in the dry season (Fisher's exact test: $\mathrm{p}=0.009)$. Although Sherman ground also showed higher capture success in the dry season, the difference between

Table 1. Capture success (\%) in each habitat for different trap types in a fragmented landscape at Fazendinha Agroecológica, Km 47, Seropédica municipality, Rio de Janeiro state, Southeastern Brazil. TN = Number of trap-nights; TC $=$ total of captures per habitat; $\mathrm{SC}=$ capture success $(\mathrm{TC} / \mathrm{TN} \times 100) ; \mathrm{Da}=$ Didelphis aurita, $\mathrm{Pf}=$ Philander frenatus, $\mathrm{Ac}=$ Akodon cursor, $\mathrm{On}=$ Oligoryzomys nigripes, $\mathrm{Mm}=$ Mus musculus, $\mathrm{Rn}=$ Rattus norvegicus. Values in parenthesis refer to the number of captures in each case.

\begin{tabular}{|c|c|c|c|c|c|c|c|c|c|c|}
\hline Trap type & Habitat & TN & Da & Pf & Ac & On & $\mathrm{Mm}$ & Rn & $\mathrm{TC}$ & SC (\%) \\
\hline \multirow[t]{4}{*}{ PITFALL } & Fragment A & 592 & $3.55(21)$ & 0 & $3.94(18)$ & $2.20(13)$ & $0.17(1)$ & 0 & 53 & 8.95 \\
\hline & Fragment B & 543 & 0.74 (4) & 0 & $2.03(11)$ & $1.10(6)$ & 0 & 0 & 21 & 3.87 \\
\hline & Corridor & 541 & $0.74(4)$ & 0 & $0.18(1)$ & 0.74 (4) & $0.37(2)$ & 0 & 11 & 2.03 \\
\hline & Pasture & 508 & 0 & 0 & $0.39(2)$ & $0.20(1)$ & 0 & 0 & 3 & 0.59 \\
\hline TOTAL & & 2184 & 1.33 (29) & 0 & $1.47(32)$ & $1.10(24)$ & $0.14(3)$ & 0 & 88 & 4.03 \\
\hline SHERMAN & Fragment A & 327 & $4.28(14)$ & 0 & $1.22(4)$ & 0 & 0 & 0 & 18 & 5.50 \\
\hline \multirow[t]{3}{*}{ GROUND } & Fragment B & 299 & $0.33(1)$ & $1.67(5)$ & $0.33(1)$ & $1.34(4)$ & 0 & 0 & 11 & 3.68 \\
\hline & Corridor & 320 & 0 & $0.31(1)$ & $0.63(2)$ & 0 & 0 & 0 & 3 & 0.93 \\
\hline & Pasture & 563 & $0.18(1)$ & 0 & $1.96(11)$ & 0 & 0 & 0.18 (1) & 13 & 2.30 \\
\hline TOTAL & & 1509 & $1.06(16)$ & $0.40(6)$ & $1.19(18)$ & $0.27(4)$ & 0 & 0.07 (1) & 45 & 2.98 \\
\hline SHERMAN & Fragment A & 312 & $5.13(16)$ & 0 & - & - & - & - & 16 & 5.12 \\
\hline \multirow[t]{2}{*}{ TREE } & Fragment B & 294 & $1.02(3)$ & $1.02(3)$ & - & - & - & - & 6 & 2.04 \\
\hline & Corridor & 323 & 0 & 0 & - & - & - & - & 0 & 0 \\
\hline TOTAL & & 929 & $2.05(19)$ & $0.32(3)$ & - & - & - & - & 22 & 2.37 \\
\hline
\end{tabular}


Table 2. Capture success (\%) of small mammals during wet and dry seasons for three different trap types used in a fragmented landscape at FazendinhaAgroecológica Km 47, Seropédica municipality, Rio de Janeiro state, Southeastern Brazil. Values in parenthesis are the number of captures per sampling effort.

\begin{tabular}{|c|c|c|c|c|}
\hline Species & Season & Pitfall & Sherman ground & Sherman tree \\
\hline \multicolumn{5}{|l|}{ RODENTS } \\
\hline \multirow{2}{*}{ Akodon cursor } & Wet & $2.26(28 / 1239)$ & $0.92(8 / 870)$ & - \\
\hline & Dry & $0.42(4 / 945)$ & $1.56(10 / 639)$ & - \\
\hline \multirow[t]{2}{*}{ Oligoryzomys nigripes } & Wet & $1.78(19 / 1239)$ & $0.34(3 / 870)$ & - \\
\hline & Dry & $0.21(2 / 945)$ & $0.16(1 / 639)$ & - \\
\hline \multirow[t]{2}{*}{ Mus musculus } & Wet & $0.24(3 / 1239)$ & 0 & - \\
\hline & Dry & 0 & 0 & - \\
\hline \multirow[t]{2}{*}{ Rattus norvegicus } & Wet & 0 & $0.11(1 / 870)$ & - \\
\hline & Dry & 0 & 0 & - \\
\hline \multirow[t]{3}{*}{ TOTAL RODENTS } & Wet & $4.28(53 / 1239)$ & $1.38(12 / 870)$ & - \\
\hline & Dry & $0.63(6 / 945)$ & $1.72(11 / 639)$ & - \\
\hline & Total & $2.70(59 / 2184)$ & $1.52(23 / 1509)$ & - \\
\hline MARSUPIALS & & & & - \\
\hline \multirow[t]{2}{*}{ Didelphis aurita } & Wet & $2.26(28 / 1239)$ & $1.26(11 / 870)$ & $0.91(5 / 547)$ \\
\hline & Dry & $0.11(1 / 945)$ & $0.78(5 / 639)$ & $3.66(14 / 382)$ \\
\hline \multirow[t]{2}{*}{ Philander frenatus } & Wet & 0 & $0.23(2 / 870)$ & $0.18(1 / 547)$ \\
\hline & Dry & 0 & $0.63(4 / 639)$ & $0.52(2 / 382)$ \\
\hline \multirow[t]{3}{*}{ TOTAL MARSUPIALS } & Wet & $2.26(28 / 1239)$ & $1.49(13 / 870)$ & $1.10(6 / 547)$ \\
\hline & Dry & $0.11(1 / 945)$ & $1.41(9 / 639)$ & $4.19(16 / 382)$ \\
\hline & Total & $1.33(29 / 2184)$ & $1.46(22 / 1509)$ & $2.37(22 / 929)$ \\
\hline \multirow[t]{3}{*}{ TOTAL (RODENTS AND MARSUPIALS) } & Wet & $6.50(81 / 1239)$ & $2.87(25 / 870)$ & $1.10(6 / 547)$ \\
\hline & Dry & $0.11(1 / 945)$ & $3.13(20 / 639)$ & $4.19(16 / 382)$ \\
\hline & Total & $4.03(88 / 2184)$ & $2.98(45 / 1509)$ & $2.37(22 / 929)$ \\
\hline
\end{tabular}

seasons was not significant for this kind of trap (Fisher's exact test: $\mathrm{p}=0.757$; Table 2).

Regarding each taxonomic group separately, marsupials showed no significant differences between traps in the wet season $\left(\chi^{2}=3.52, p=0.172\right)$, whereas in the dry season Sherman tree was the most efficient trap, followed by Sherman ground and pitfall $\left(\chi^{2}=34.799, p<0.0001\right)$. As for rodents, the higher values were achieved for pitfall in the wet season (Fisher's exact test, $p=0.0002$ ), whereas in the dry season the pattern inverted, showing Sherman ground as the most efficient trap (Fisher's exact test: $\mathrm{p}=0.047$; Table 2).

Considering each species separately, analyses were possible just for D. aurita and A. cursor, as for the other species, the low number of captures did not allow any comparisons. For D. aurita the capture success did not differ among trap types in the wet season $\left(\chi^{2}=5.44\right.$, $\mathrm{p}=0.066)$, although pitfall trapping efficiency had been almost the triple of Sherman tree. In the dry season, Sherman tree was the most efficient of all in capturing this marsupial, followed by Sherman ground and pitfall $\left(\chi^{2}=34.74, \mathrm{p}<0.0001\right)$. For $A$. cursor, the highest capture success in the wet season was achieved with pitfalls (Fisher's exact test: $p=0.031$ ) while Shermans were the most efficient traps in the dry season (Fisher's exact test: $\mathrm{p}=0.026$; Table 2).

\section{Discussion}

Pitfalls had higher total capture success than Sherman traps placed either on the ground or in trees, confirming similar results found in several habitats in Brazil, which found that pitfalls were three to eight times more efficient (Lyra-Jorge and Pivello, 2001; Hice and Schmidl, 2002; Umetsu et al., 2006). This high efficiency of capture observed for pitfalls may be related to the likelihood of capturing more than one individual in the same trap, which was observed during this study on many occasions.

Another factor to be considered is that the chance of capture in this kind of trap increases with the drift fences that direct the animals to the pitfalls. In addition, as baits are not usually put in pitfalls, these traps are not affected either by food availability (Adler and Lambert, 1997), by preference of species for kinds of baits (Laurance, 1992), or by bait removal by ants (Mcclearn et al., 1994). However, as baits were used in our study we cannot discard the hypothesis that they could have acted as attractors for some species.

Some authors also suggest that Sherman traps or similar methods do not capture young individuals or species with very reduced body weight, as trap triggers are little sensitive to their weight (Maddock, 1992; LyraJorge and Pivello, 2001; Francl et al., 2002). This could possibly explain, for instance, the low capture frequency 
of individuals from $O$. nigripes in this kind of trap in this study. Besides, in spite of the low number of captures of Mus musculus, individuals of this species were also captured only in pitfalls.

Nevertheless, some studies found higher efficiency for Sherman traps when compared to pitfalls (Petersen, 1980; Silva, 2001; Santos-Filho et al., 2006). Most studies achieving these results used less deep pitfalls (in general $<$ $40 \mathrm{~cm}$ depth), which may ease animal escape. Generally, whenever pitfalls were more efficient, pitfalls were deeper $(>60 \mathrm{~cm})$, just like the ones used in this experiment.

Considering the efficiency of trap types for marsupials and rodents separately, we observed that there was a higher number of captures in pitfalls for rodents, which may be partially explained by the fact that Sherman traps do not usually capture any individuals with reduced body weight, as already mentioned. Yet, there was no significant difference between the capture methods for marsupials. In spite of this, it is important to note that Philander frenatus (Olfers, 1818) was caught only in Sherman traps. This result can suggest that this marsupial could avoid pitfalls traps or that these animals are able to escape from them. In fact, Delciellos and Vieira (2009) showed that $P$. frenatus had the better jumping ability among terrestrial didelphid marsupials. The effects of such ability, found also in other marsupial species like $D$. aurita, should be investigated in future studies comparing the efficiency of different trap types.

The higher efficiency of pitfalls during the wet season has been reported by other authors in the Brazilian Atlantic Forest (Santos-Filho et al., 2006) and Amazon Rainforest (Hice and Schmidl, 2002). According to Handley and Varn (1994) and Silva et al. (2000), pitfalls would be more efficient in the wet season, as soaking prevents animals from escaping. Nevertheless, this explanation does not apply in this work, as we used big pitfalls which decrease the chance for animals to escape after falling. We believe that the higher capture in pitfalls in the wet season could reflect animal movement patterns. Climatic factors can alter animal activity, which in turn can affect the probability of animals finding traps (Stokes et al., 2001). In the wet season animals can be more active and move longer distances due to a decrease in predation chance caused by a reduction in the number of nights with high luminosity (Stokes et al., 2001). Besides that, heavy rain can promote the dislodgement of individuals of terrestrial species from dens (Umetsu et al., 2006). This higher movement rate, in turn, can facilitate capture in pitfalls traps. In the same station, in spite of Shermans being able to be more easily found, the higher availability of food resources in the forest can make this kind of trap less attractive. In fact, in other studies using only Sherman traps there was higher capture success during dry periods (Stallings, 1990; Grelle, 1996). Adler and Lambert (1997), estimating rodent density in Panama islands, found a negative relationship between the capture of frugivorous rodents and the number of fruit trees bearing fruit. According to Adler and Lambert (1997), small mammals are harder to capture in traditional traps in periods of higher availability of food supply. Experiments carried out in the same area of our study showed less food availability in the dry season, with less abundance and richness of arthropods (Martins, 2009), and less fruit availability than in the rainy months (Vieira, 2007).

Another factor to be considered is that in the wet season most populations of small mammals are usually composed mostly by young animals (Vieira, 1996; Quental et al., 2001). According to Mares and Ernest (1995), most species of small mammals reproduce at the end of the dry period and the beginning of the rainy season. Density peak occurs in mid wet season, when many young individuals of the population are recruited. These individuals tend to move more than adults, which have already established home ranges (Graipel and Santos-Filho, 2006). Such high displacement could favour capture in interception and fall traps. Moreover, due to their low weight, young individuals tend to have lower capture rate in Sherman traps or similar methods (O'Connell, 1989; Vieira, 1996; Quental et al., 2001).

The capture success of different trap types also varied between habitats, which may be due to differences in the composition and abundance of small mammal species in each area. Pitfalls were more efficient in the fragment A and corridor. These habitats were dominated by rodents, which are generally captured more in pitfalls, as found in other studies (Silva, 2001; Lyra-Jorge and Pivello, 2001; Umetsu et al., 2006). For the corridor, besides the higher capture of rodents, there was also no capture in Sherman tree traps, probably due to its thin canopy. In the pasture, although rodents also were the most abundant group, Sherman ground had the higher capture rate. A possible explanation for this is the smaller home ranges in highly productive areas like grassland where arthropod availability is usually high (Pires et al., 2005). This fact reduces the likelihood of these animals to find drift fences and be directed to the pitfalls due to their reduced locomotion. As Sherman was closer among them, in comparison with pitfall systems, it can be more easily found in this situation.

Concluding, the efficiency of capture methods of small mammals varied according to the kind of trap, taxonomic group, season, and habitat. The results found for taxonomic groups made evident that combining different trap types is important to increase the total trapping success and the acquisition of more representative community data. Considering variations among seasons and habitats, our results demonstrated a complex effect of these factors in trap efficiency and the capture of different taxonomic groups. Nonetheless, as our study comprised just a year and the number of replicates for each habitat was low, generalisations are not possible. Future studies investigating differential success of trap types in small mammal communities should focus on this question.

\section{Acknowledgements}

This study is part of the Master's degree thesis of A.L.M. Vieira, who received a scholarship from CAPES. Thanks are due to the Programa de Pós-Graduação em Ciências 
Ambientais e Florestais/UFRRJ for support and also to Fernando Fernandez who kindly loaned the traps used in this study. We also thank the colleagues who helped during field work. Fernando Fernandez, Marcus Vinícius Vieira and an anonymous reviewer provided valuable comments on an earlier version of this manuscript.

\section{References}

ADLER, GH. and LAMBERT, TD., 1997. Ecological correlates of trap response of a Neotropical forest rodent, Proechimys semispinosus. Journal of Tropical Ecology, vol. 13, no. 1, p. 59-68. http://dx.doi.org/10.1017/S0266467400010257.

ASTÚA, D., MOURA, RT., GRELLE, CEV. and FONSECA, MT., 2006. Influence of baits, trap type and position for small mammal capture in a Brazilian lowland Atlantic Forest. Boletim do Museu de Biologia Mello Leitão, vol. 19, no. 1, p. 31-44.

BERGALLO, HG. and MAGNUSSON, WE., 1999. Effects of climate and food availability on four rodent species in southeastern Brazil. Journal of Mammalogy, vol. 80, no. 2, p. 472-486. http:// dx.doi.org/10.2307/1383294.

DELCIELLOS, AC. and VIEIRA, MV., 2009. Jumping ability in the arboreal locomotion of didelphid marsupials. Mastozoología Neotropical, vol. 16, no. 2, p. 299-307.

FRANCL, KE., FORD, WM. and CASTLEBERRY, SB., 2002. Relative efficiency of three small mammal traps in central Appalachian wetlands. Georgia Journal of Science, vol. 60, no. 4, p. 194-200.

FREITAS, D. and FERNANDEZ, FAS., 1998. Efficiency of small mammal trapping in Brazilian Atlantic forest fragments: the effects of trap type and position. Vida Silvestre Neotropical, vol. 7 , no. $2-3$, p. $27-33$

GRAIPEL, ME. and SANTOS-FILHO, M., 2006. Reprodução e dinâmica populacional de Didelphis aurita Wied-Neuwied (Mammalia: Didelphimorphia) em ambiente periurbano na Ilha de Santa Catarina, Sul do Brasil. Biotemas, vol. 19, no. 1, p. 65-73.

GRELLE, CEV., 1996. Análise tridimensional de uma comunidade de pequenos mamíferos. Belo Horizonte: Universidade Federal de Minas Gerais. 56 p. Dissertação de Mestrado em Ecologia.

HANDLEY, CO. and VARN, M., 1994. The trapline concept applied to pitfall arrays. In MERRITT, JF.,KIRKLAND, GL. and ROSE, RK. (Eds.). Advances in the biology of shrews. Pittsburgh: Carnegie Museum of Natural History. p. 285-286. Special Publication, no. 18.

HICE, CL. and SCHMIDL, YDJ., 2002. The effectiveness of pitfall traps for sampling small mammals in the Amazon Basin. Mastozoología Neotropical, vol. 9, no. 1, p. 85-89.

LAURANCE, WF., 1992. Abundance estimates of small mammals in Australian tropical rainforest: a comparison of four trapping methods. Wildlife Research, vol. 19, no. 6, p. 651-655. http:// dx.doi.org/10.1071/WR9920651.

LAURANCE, WF., 1994. Rainforest fragmentation and the structures of small mammal communities in tropical Queensland. Biological Conservation, vol. 69, no. 1, p. 23-32. http://dx.doi. org/10.1016/0006-3207(94)90325-5.

LEE, LL., 1997. Effectiveness of live traps and snap traps in trapping small mammals in kinmen. Acta Zoologica Taiwanica, vol. 8 , no. 2 , p. $79-85$.
LIRA, PK., FERNANDEZ, FAS., CARLOS, HSA. and CURZIO, PL., 2007. Use of a fragmented landscape by three species of opossum in south-eastern Brazil. Journal of Tropical Ecology, vol. 23, no. 4, p. 427-435. http://dx.doi.org/10.1017/S0266467407004142.

LYRA-JORGE, MC. and PIVELLO, VR., 2001. Combining live trap and pitfall to survey terrestrial small mammals in savanna and forest habitats in Brazil. Mammalia, vol. 65, no. 4, p. 524-530.

MADDOCK, AH., 1992. Comparison of two methods for trapping rodents and shrews. Israel Journal of Zoology, vol. 38, no. 5 , p. 333-340.

MARES, MA. and ERNEST, KA., 1995. Population and community ecology of small mammals in a gallery forest of central Brazil. Journal of Mammalogy, vol. 76, no. 3, p. 750-768. http://dx.doi. org/10.2307/1382745.

MARTINS, EM., 2009. Fauna do solo e fungos micorrizicosarbusculares em um corredor agroflorestal. Seropédica: Universidade Federal Rural do Rio de Janeiro. 61 p. Dissertação de Mestrado em Ciências Ambientais e Florestais.

MCCLEARN, D., KOHLER, J., MCGOWAN, KJ.,CEDENO, E., CARBONE, LG. and MILLER, D., 1994. Arboreal and terrestrial mammal trapping on Gigante Peninsula, Barro Colorado. Nature Monument, Panama. Biotropica, vol. 26, no. 2, p. 208-213. http:// dx.doi.org/10.2307/2388810.

O'CONNELL, MA., 1989. Population dynamics of Neotropical small mammals in seasonal habitats. Journal of Mammalogy, vol. 70, no. 3, p. 532-548. http://dx.doi.org/10.2307/1381425.

O'FARRELL, MJ., CLARK, WA., EMMERSON, FH., JUAREZ, SM., KAY, FR., O'FARRELL, TM. and GOODLETT, TY., 1994. Use of mesh live traps for small mammals: are results from Sherman live traps deceptive? Journal of Mammalogy, vol. 75, no. 3, p. 692-699. http://dx.doi.org/10.2307/1382517.

PETERSEN, MKA., 1980. Comparison of small mammal populations sampled by pit-fall and livetraps in Durango, Mexico. The Southwestern Naturalist, vol. 25, no. 1, p. 122-124. http:// dx.doi.org/10.2307/3671228.

PIRES, AS., LIRA, PK., FERNANDEZ, FAS., SCHITTINI, GM. and OLIVEIRA, LC., 2002. Frequency of movements of small mammals among Atlantic Coastal Forest fragments in Brazil. Biological Conservation, vol. 108, no. 2, p. 229-237. http://dx.doi. org/10.1016/S0006-3207(02)00109-X.

PIRES, AS., FERNANDEZ, FAS., FREITAS, D. and FELICIANO, BR., 2005. Influence of edge and fire-induced changes on spatial distribution of small mammals in Brazilian Atlantic Forest fragments. Studies on Neotropical Fauna and Environment, vol. 40, no. 1, p. 7-14. http://dx.doi.org/10.1080/01650520412331333747.

QUENTAL, TB., FERNANDEZ, FAS., DIAS, ATC. and ROCHA, FS., 2001. Population dynamics of the marsupial Micoureusdemerarae in small fragments of Atlantic Coastal Forest in Brazil. Journal of Tropical Ecology, vol. 17, no. 3, p. 339-352. http://dx.doi. org/10.1017/S0266467401001237.

SANTOS-FILHO, M., SILVA, DJ. and SANAIOTTI, TM., 2006. Efficiency of four trap types in sampling small mammals in Forest fragments, Mato Grosso, Brasil. Mastozoología Neotropical, vol. 13, no. 2, p. 217-225.

SANTOS-FILHO, M., SILVA, DJ. and SANAIOTTI, TM., 2008. Variação sazonal na riqueza e na abundância de pequenos mamíferos, na estrutura da floresta e na disponibilidade de artrópodes em fragmentos florestais no Mato Grosso, Brasil. Biota 
Neotropica, vol. 8, no. 1, p. 115-121. http://dx.doi.org/10.1590/ S1676-06032008000100014.

SCHITTINI, G., OLIVEIRA, LC. and FERNANDEZ, FAS., 2002. Influence of different trap types and positions on the characterization of small mammal communities of Atlantic forest fragments at Poço das Antas Biological Reserve, RJ. Bios, vol. 10, p. 55-61.

SILVA, M., CAMERON, J. and PUDDISTER, C., 2000. Small mammal abundance and community composition in Prince Edwards Island National Park. Canadian Field Naturalist, vol. 114 , no. 1 , p. 26-33.

SILVA, CR., 2001. Riqueza e diversidade de mamíferos nãovoadores em um mosaico formado por plantio de Eucalyptussaligna e remanescentes de Floresta Atlantica no município de Pilar do Sul, SP. Piracicaba: Escola Superior de Agricultura Luiz de Queiroz. 81 p. Dissertação de Mestrado em Ciências Agrárias.

SLADE, NA., EIFLER, MA., GRUENHAGEN, NM. and DAVELOS, AL., 1993. Differential effectiveness of standard and long Sherman livetraps in capturing small mammals. Journal of Mammalogy, vol. 74, no. 1, p. 156-161. http://dx.doi.org/10.2307/1381915.

SLADE, NA. and RUSSELL, LA., 1998. Distances as indices to movements and home-range size from trapping records of small mammals. Journal of Mammalogy, vol. 79, no. 1, p. 346-351. http://dx.doi.org/10.2307/1382871.

STALLINGS, JR., 1990. The importance of understorey on widlife in a Brazilian eucalipt plantation. Revista Brasileira de
Zoologia, vol. 7, no. 3, p. 267-276. http://dx.doi.org/10.1590/ S0101-81751990000300008.

STOKES, MK., SLADE, NA. and BLAIR, SM., 2001. Influences of weather and moonlight on activity patterns of small mammals: a biogeographical perspective. Canadian Journal of Zoology, vol. 79, no. 6, p. 966-972. http://dx.doi.org/10.1139/z01-059.

UMETSU, F., NAXARA, L. and PARDINI, R., 2006. Evaluating the efficiency of pitfall traps for sampling small mammals in the neotropics. Journal of Mammalogy, vol. 87, no. 4, p. 757-765. http://dx.doi.org/10.1644/05-MAMM-A-285R2.1.

VIEIRA, MV., 1996. Dynamics of a rodent assemblage in a Cerrado of Southeast Brazil. Revista Brasileira de Biologia, vol. 57, no. 1, p. 99-107.

VIEIRA, ALM., 2007. Potencial econômico-ecológico de sistemas agroflorestais para conexão de fragmentos da mata Atlântica. Seropédica: Universidade Federal Rural do Rio de Janeiro. 69 p. Monografia de Conclusão de Curso em Engenharia Florestal.

VIVAN, JL., 1998. Agricultura e florestas: princípios de uma interação vital. Rio de Janeiro: Agropecuária/AS-PTA. 208 p.

WOODMAN, N., TIMM, RN., SLADE, NA. and DOONAN, TJ., 1996. Comparison of traps and baits for censuring small mammals in neotropical lowlands. Journal of Mammalogy, vol. 77, no. 1, p. 274-281. http://dx.doi.org/10.2307/1382728.

ZAR, JH., 1999. Biostatistical analysis. New Jersey: Prentice Hall. 929 p. 